\title{
DISE Learning Model for Teaching Writing to Elementary School Students
}

\author{
Ani Widosari, Sarwiji Suwandi, Slamet, Retno Winarni \\ Sebelas Maret University, Surakarta, Indonesia
}

\begin{abstract}
DISE learning model refers to the one which is dialogue-based using scientific approach containing edutainment element. DISE is the acronym of dialog, scientific, and edutainment. It is a learning model which is developed for the fifth graders of elementary school particularly for teaching writing of personal recount. This article described DISE learning model from the theoretical basis, meaning, and syntax. DISE was the product of Research and Development design conducted in Banyumas Regency, Central Java Province, Indonesia. DISE learning model can serve as a reference for elementary school teachers for teaching writing.
\end{abstract}

Keywords: DISE model, syntax, writing, elementary school

\section{Introduction}

Literacy is the educational term which every country in the world always keeps developing and striving for it. Foley (1994) used the term "literacy" to refer to the mastery of language, in both its spoken (augmented) and written forms, which enables an individual to use language fluently for a variety of purposes. UNESCO (United Nations Educational Scientific and Cultural Organization) (2006) defined literacy as a set of tangible skills - particularly the cognitive skills of reading and writing as well as oral skills. Both definitions mean that literacy refers to the integration of listening, speaking, reading, and writing skills aimed at building the habit of critical thinking.

Most people are easy to deliver their ideas and thoughts in oral than in written although both are important as a means of communication. Writing is considered as the most complicated and challenging language skill compared to the other three ones as it has to produce correct and appropriate text. So many language components need to be included in writing such as grammar, punctuation, spelling, and vocabulary. Writing also needs the processes of planning, drafting, editing, revising, and evaluating. More efforts are required to produce meaning through writing than through the other skills.

Writing as one of literacy skills belongs to a learning process. Students need to be taught and get accustomed to it. UNESCO (2006) viewed literacy as an active and broad-based learning process, rather than as a product of a more limited and focused educational intervention. Writing as literacy skill is only developed through educational process by teaching students how to write and giving opportunities to practice it.

Ani Widosari, S.Pd., M.Pd., a student of Doctoral Program of Language Education, Sebelas Maret University, Surakarta, Indonesia.

Sarwiji Suwandi, Professor Doktor, M.Pd., Department of Language Education, Sebelas Maret University, Surakarta, Indonesia. Slamet, Professor Doktor, M.Pd., Department of Language Education, Sebelas Maret University, Surakarta, Indonesia. Retno Winarni, Professor Doktor, M.Pd., Department of Language Education, Sebelas Maret University, Surakarta, Indonesia. 
Literacy can be seen in terms of subject matter and the nature of the texts that are produced (UNESCO, 2006). The content standard of the school subject of Indonesian language contains literacy concept. Literate culture is developed to acquire language ability. Students are expected to have literacy skills. Writing and reading are two competencies which cannot be separated and are closely related. The reading habit will ease writing activity.

Teaching literacy to elementary school students, particularly in teaching writing, is not simple but vitally important. Although writing is a complex skill, it can be an engaging, interesting, and even inspiring activity as long as it is learned through social interaction by considering their characteristics as young learners. It needs a learning model which will best help the students to do so.

\section{The Characteristics of Elementary School Students}

Age plays a distinctive role in what and how to teach. Elementary school students in Indonesia, formally, begin at the ages 7 to 12 years old and they are called as the first to the sixth graders. The first and second graders (7-8 years old) belong to minimal level, the third and fourth ones (9-10 years old) are categorized moderate level, while the fifth and sixth graders (11-12 years old) can be categorized strong level. According to the US Department of Education (2012), the students in the minimal level are just beginning to learn letter and to write words and simple sentence while those who are in the moderate level are learned to become fluent with handwriting, spelling, sentence construction, typing, and word processing. How to use the writing process for a variety of purposes becomes the target of writing in the strong level.

This research focuses on teaching writing for the fifth graders of elementary school. The students in this grade have typical characteristics based on their ages. Ersoz (2007) named the students in 10-12 years old as "late young learners" and the characteristics of this group of students are: (1) They have longer attention spans, but are still children; (2) they either take learning more seriously or are very easily bored and distracted; (3) they possess some world knowledge and are technologically skilled/oriented; (4) they are more willing to cooperate in groups and pairs; (5) they have already developed social, motor, and intellectual skills; and (6) although they are still developing their learning strategies, they make use of them in order to learn more effectively.

In elementary school, students are encountering the elements of writing for the first time. They have to learn gradation of writing skills such as: (1) form letters; (2) spell words; (3) use correct grammar; (4) use complete sentences; (5) begin sentences with capital letters; (6) end sentences with appropriate punctuation; (7) capitalize pronoun, place names, people's names, months, holidays, etc.; (8) write stories with a beginning, middle, and an end; (9) use transitional words to show sequence of events (after, next, now, finally); (10) respond in writing toward texts; (11) write informative reports; (12) stay on topic and provide supporting detail; (13) generate ideas; and (14) attempt to correct errors. They are expected to advance from learning the writing rules to automatically applying them. By the end of elementary school, they should be able to write independently and produce multiple-paragraphs which contain a beginning, middle, and an end.

\section{Teaching Writing Personal Recount}

Writing becomes the fundamental skill of literacy besides reading. It is vitally important for academic purposes and someone's development and learning. Teaching writing in elementary school can be varying from state to state and school to school, but there are some general expectations. It aims at moving the students from writing words and sentences to writing stories and short informative pieces. 
Writing personal recount becomes the material of Indonesian language school subject for the fifth graders in semester 1 of elementary school. According to Content Standard of Indonesian Elementary School proposed by BSNP (2006), the competence standard for writing skill in grade 5 is expressing thought, feeling, information, and experience in written text, invitation, and written dialog; while one of its basic competences is writing a text based on experience by considering diction and spelling. Students need opportunities to experience literature representing a genre of recount. They need to be taught about its purpose, organization, details, and voice/tone of recount text. Developing literacy in young children can be done through writing personal recount as students are demanded to identify the five $\mathrm{Ws}_{\mathrm{s}}$-who, when, what, where, why — upon their experience. They also learn about how to put events in chronological orders by using first, next, then, and last. In this research, they are asked to write their experience both happy and sad. Serra (2014) argued that asking young learners to write about their own lives and experiences becomes one of tips to encourage young learners to write. Their experience can be about their holiday or their experience with their grandparents, or any other personal experience outside the classroom. Writing personal recount has been in line with the characteristics of young children. Harmer (2007) stated that young children like to talk about themselves and respond to learning that uses their lives as the main topic as well as understand mostly when they see, hear, touch, and interact rather than from explanations. They are taught to be young writers who best write about something they know well.

\section{DISE (Dialog, Scientific, Edutainment) Learning Model}

The success of language teaching and learning process does not merely depend on the input quality of students and teachers mastery. The implementation of good and appropriate learning model in the classroom plays a great role. Teaching means transferring knowledge in such a way that can make the learners interested in the subject, enjoy the process, and understand the material taught, one of which is through a learning model.

DISE learning model is the acronym of Dialog-Scientific-Edutainment. It is a learning model which is dialog-based using scientific approach and containing edutainment element. It must have five basic elements proposed by Joyce and Weil (2011) as follows:

(1) Syntax

Syntax means standardized operational stages of learning. A learning model needs syntax for the sake of being guidance for teachers who apply it. The syntax of DISE are: (a) creating students involvement circumstance by scientific approach; (b) presenting a problem to be discussed through dialog and edutainment; (c) constructing mind-mapping; and (d) developing mind-mapping to be a recount text.

(2) Social system

Social system is a learning process to recognize, analyze, and consider the existence and behavior of students and teachers as social institution within learning process. DISE learning model uses multidirectional communication between teachers and students and among students. They were involved in a dialog questioning each other by five $W \mathrm{~s}$ - what, who, when, where, why and one $H$ - How.

(3) Principles of reaction

Principles of reaction include students' reactions toward learning activities applied by the teacher as well as the teacher technique in giving reaction toward students' behavior. During the implementation of DISE learning model, students' reactions became planned and not incidental activities. They enjoyed and were passionate in writing. 
(4) Support system

Support system is supporting component in implementing a learning model. Well-organized materials and procedures of learning model serve as the examples of support system. DISE learning model has support system such as lesson plan, syllabus, modeling book, textbook, observation sheet, and writing scoring rubric. Single picture, serial pictures, and video can also serve support system.

(5) Instructional objective and nurturant effect

Instructional objective means behaviors resulted from learning process which is expected, owned, or acquired by students; it more focuses on the knowledge domain. Nurturant effect comes from experiencing the environment created by the model; it more focuses on the affective domain. The instructional objectives of DISE learning model are: (1) the ability to observe, give questions, think, analyze, and communicate; (2) the improvement of students' autonomy and liveliness; and (3) the improvement of writing ability. The nurturant effects of DISE can be seen from questioning activity which can develop students to be brave, honest, confident, and responsible while the dialog process can build social attitude, cooperation, and one-to-another appreciation.

DISE learning model is the combination between interactional model and genre model in language teaching. Richards (2014) stated that interactional model underlines interactive perspective in language education. Students achieve facility in using a language when their attention is focused on conveying and receiving authentic message containing information of interest to both speaker and listener. Through dialoging five $W$ s and one how questions, DISE learning model accommodates interactive perspective. DISE also belongs to genre model as it uses text as functional model of language, in this case, personal recount text. Students learn norms of language usage in recount text that it must contain information about five $W$ s and one how questions.

\section{Dialog}

Dialog is useful for a wide range of teaching and learning purposes in classroom. It provides the link between oral and literate forms of interpreting, understanding, and transforming the world. Dialog is intended to imply a deeper level of analysis or explanation compared to isolated monolog. Learning is a process of guided participation and one of which is mediated through dialog. It can be used to practice pronunciation, stress, and intonation or even becomes a model to invent information.

According to Grugeon and Hubbard (2010), dialog taking place in the classroom between teachers and students and between students can be a powerful learning tool. Dialog can promote higher level of interaction and cognitive engagement. Teaching through dialogue means teachers encourage children to listen to each other, share ideas, and consider alternatives; build on their own and others' ideas to develop coherent thinking; express their views fully and help each other to reach common understandings.

The key focus is on children telling and listening and involves students as speakers as well as listeners. Martin, Lovat, and Prnell (2007) stated in order to be able to begin writing, children need experience of oral language; writing means moving from oral to literate language. In DISE learning model, dialog was employed to dig information related to students experience both happy and sad. Dialog is suitable applied for elementary school students as they are peer-conscious and may be very concerned about what classmates think. They like participating and interacting in group activities. They are often inquisitive and need to express their opinions. Dialoging in pair work in DISE was carried out by questioning the five $W \mathrm{~s}$ - and one $H$-How based on the guided questions as follows: (1) What was your happy/sad experience; (2) When did it happen; (3) Who were involved in that event; (4) Where did it happen; (5) What did you feel about your experience; and (6) Why did it happen. 


\section{Scientific Approach}

Scientific Approach (SA) is the second element in DISE learning model. In Indonesia, this approach has been used in Curriculum 2006-KTSP and becomes mainly being emphasized in Curriculum 2013. SA was chosen to be the only approach taken in the Curriculum 2013 based on the argument that learning is a scientific process in the classroom. Thus, learning must be scientific-based by following some steps of learning, i.e., observing, questioning, trying, thinking, presenting, and creating.

SA needs to be combined with others approaches, methods, or theories of language teaching and learning, one of which is Genre-Based Approach (GBA). In this research, SA is associated with writing personal recount which includes in GBA. Writing as a process must be taught to students to arouse their awareness on the purpose of writing. Writing is not merely a product of ideas documentation but it is a process of thinking carefully. Students have to plan what to write, understand what the readers want to know, and how to write it in a good order. They need a process of planning, drafting, sharing, revising, editing, and even sharing the final product.

Scientific approach (SA) can be applied during the writing process by involving the students in the learning process using five stages as follows:

(a) Observing

Observing activity in the DISE model is carried out by observing pictures, environment, and video.

(b) Questioning

Questioning is conducted by asking the question words of how, who, when, where, why, and what. It aims at expressing something based on what students think.

(c) Thinking

Thinking in the DISE model is done by thinking on what has been asked. Teachers can give keywords to ease students in developing personal recount.

(d) Trying/analyzing

Trying stage is carried out by trying to write personal recount based on the mind mapping students had made.

(e) Communicating

Students communicate orally to their friends or teacher about their personal recount both happy and sad experiences.

The stages of scientific approach are not always done in sequence; they depend on the condition and situation of the students. The stages may begin with questioning or communicating first and then followed by the other stages.

Learning is a constructivist process in which every student constructs their own knowledge and meanings. At the conceptual level, there has been an important transition from a knowledge acquisition view of learning to a knowledge construction view of learning (Suomala \& Shaughnessy, 2000). Teachers have to develop student's individual thinking and reasoning so that he or she can appraise that information and separate the relevant from irrelevant and the important from the trivial. By scientific approach (observing, questioning, thinking, trying/analyzing, and communicating) applied in DISE learning model, students were involved in knowledge construction of writing personal recount. 


\section{Edutainment}

Edutainment derived from the words of education and entertainment. It is a form of entertainment designed to educate as well as to amuse by embedding lesson in entertainment media such as TV program, video, games, song, and so forth. It can also be done by integrating technology in learning process. To Buckingham and Scanlon (2000), "Edu-tainment" is a hybrid genre that relies heavily on visual material, on narrative or game-like formats, and on more informal, less didactic styles of address. Edutainment functions to ignite students' interest and engage them with the subject or in the other words, it serves for entertaining learning materials. It is useful in creating learning environment-enrich delights and profound learning, particularly for young learners who like fun activities.

Edutainment element is important in teaching writing of personal recount to elementary school students for the sake of creating interesting and joyful learning for them. It can break boredom and make the learning more live. A teacher needs to design edutainment element used during the learning process based on his own ability. Edutainment should be well grounded in constructivist learning theory and consider the findings of research on educational technology and educational psychology (Okan, 2003). Thus, edutainment can be used as literacy media to teach language as it can enhance emotional and behavioral development for students. In DISE learning model, edutainment becomes the third component which can be actualized by showing picture and video of happy and sad experience. They had been engaged and entertained through visual materials before they got into the core material—writing personal recount.

\section{The Syntax of DISE}

Learning syntax refers to standardized operational stages of learning. These stages are chosen based on the learning model being developed. Syntax is needed in developing a learning model in order to be guidance for teachers to apply it. The syntax of DISE learning model for writing personal recount to elementary school students is as follows:

(1) Building involvement circumstance by Scientific Approach

Scientific Approach covers stages of observing, questioning, thinking, trying/analyzing, and communicating. The stages are described as the following: (a) observing is carried out on pictures, surrounding environment, and video; (b) questioning is conducted by the five $W \mathrm{~s}$ - what, when, who, where and one $H$-how. These question words are intended for digging students to express something in their minds; (c) thinking is done to the questions delivered. Teachers can give keywords to ease students to develop their recount text; (d) trying/analyzing is expressing from telling to writing; and (e) communicating means telling students experience both happy and sad to their friends or teacher.

(2) Presenting problem to be discussed through Dialog and Edutainment

The dialog is conducted inter-students, students to teacher, and teacher to students. It is based on the five $W_{\mathrm{s}}$ - what, when, who, where and one $H$-how which can help students to explore and have creation in arranging sentences to be interesting recount text. Edutainment is integrated during the dialog in order to create interesting and fun classroom situation. TV show, computer game, film, music, multimedia equipment, story, role-play, guessing, puzzle, song, clap-hand, yell, and so forth can be used as edutainment media.

(3) Constructing mind mapping 
Mind mapping is used to ease the students to express their ideas and thoughts to be recount texts. The mind mapping contain the questions about the five $W_{\mathrm{s}}$ - what, when, who, where and one $H$ - how.

(4) Developing mind mapping to be a recount text

Developing mind mapping to be a recount text helped and eased students in writing a story. Teacher and students were in question-answer session using five $W \mathrm{~s}$ and one $H$. Students were instructed to find out the keywords of teacher's questions which then developed to be some sentences. The sentences were expanded to be paragraphs to create a recount text.

\section{Conclusion}

DISE (Dialog-Scientific-Edutainment) is a learning model based on the dialog activity using scientific approach and containing edutainment element. It is appropriate for teaching writing personal recount in elementary school in which students are very easily bored and distracted but more willing to cooperate in groups and pairs. The syntax of DISE learning model helps to improve students' ability and passion in writing joyfully.

\section{References}

BSNP (Badan Standard Nasional Pendidikan). (2006). Retrieved on 1 November, 2016 from http://educloud.fkip.unila.ac.id/index.php?dir.../\&file=Standar\%20Isi\%20SD.pdf

Buckingham, D., \& Scanlon, M. (2000). That is edutainment: Media, pedagogy and the market place. Paper presented at The International Forum of Researchers on Young People and the Media, Sydney.

Ersoz. (2007). Teaching English to young learners. Ankara: EDM Publishing.

Foley, B. E. (1994). The development of literacy in individuals with severe congenital speech and motor impairments. In K. G. Butler (Ed.), Severe communication disorders: Intervention strategies (pp. 183-199). Gaithersburg, MD: Aspen.

Grugeon, E., \& Hubbard, L. (2010), Learning through Dialog. Retrieved on 10 September, 2016 from $\mathrm{http} / /$ cw.routledge.com/textbooks/ltps2e/data/pdfs/unit5-3.pdf

Harmer, J. (2007). The practice of English language teaching. London: Pearson Longman.

Joyce, B., Weil, M., \& Calhoun, E. (2011). Models of teaching (8th ed.). USA: Pearson Education, Inc.

Martin, T., Lovat, C., \& Prnell, G. (2004). The really useful literacy book. New York: Routledge.

Okan, Z. (2003). Edutainment: Is learning at risk? British Journal of Educational Technology, 34(3), 255-264. Retrieved on 5 December, 2016 from http://onlinelibrary.wiley.com/doi/10.1111/1467-8535.../abstract

Richards, J. C., \& Rodgers, T. S. (2014). Approaches and methods in language teaching (3rd ed.). Cambridge: Cambridge University Press. Retrieved on 15 December, 4015 from https://books.google.co.id/books?hl=id\&lr=\&id=HrhkAwAAQBAJ\&oi=fnd\&pg=PR1\&dq=dialog + approach+for+teaching + \&ots=_Kizsocjm4\&sig=XP5P9sj5BSb6M5K-IKmZjjPrX0I\&redir_esc=y\#v=onepage\&q=dialog\%20approach\%20for\%20tea ching $\& \mathrm{f}=$ false

Serra, R. (2014). How to help young English language learners love writing. Retrieved on 14 December, 2016 from https://www.britishcouncil.org/voices-magazine/how-help-young-english-language-learners-love-writing

Suomala, J., \& Shaughnessy, M. F. (2000). An interview with Richard E. Mayer: About technology. Educational Psychology Review, 12(4), 477-483.

Teaching approaches: Dialogue (2012). University of Cambridge. Retrieved on 15 December, 2016 from http://oer.educ.cam.ac.uk/wiki/Teaching_Approaches/Dialogue

UNESCO. (2006). Understandings of literacy. Retrieved on 5 October, 2016 from www.unesco.org/education/GMR2006/full/chapt6_eng.pdf

US Department of Education. (2012). Teaching elementary school students to be effective writers. Retrieved on 1 October, 2016 from ies.ed.gov/ncee/wwc/Docs/practiceguide/writing_pg_062612.pdf

teqip.com/wp-content/.../03/Kelompok-Bahasa-Inggris-1.pdf 